Agrisaintifika

Jurnal Ilmu-Ilmu Pertanian

Vol 3, No. 1, 2019

\title{
PERSEPSI PETANI TERHADAP PENGGUNAAN PUPUK ORGANIK PADA KELOMPOK TANI TRANGGULASI, KECAMATAN GETASAN, KABUPATEN SEMARANG

\author{
Rosininta Simatupang ${ }^{1}$, Sriroso Satmoko $^{2)}$, Siwi Gayatri ${ }^{3)}$
}

Fakultas Peternakan dan Pertanian, Jurusan Agribisnis, Universitas Diponegoro, Jl. Prof. Soedarto No
50275,Tembalang, Kec. Tembalang, Kota Semarang, Jawa Tengah Telp (+62) 24 7474750,
email:rosininta14@gmail.com

\begin{abstract}
Abstrak
Tujuan penelitian adalah untuk mendeskripsikan karakteristik internal dan eksternal petani sayuran organik, mendeskripsikan persepsi petani terhadap penggunaan pupuk organik dan menganalisis hubungan antara karakteristik internal dan eksternal petani dengan persepsi petani untuk menggunakan pupuk organik pada kelompok tani Tranggulasi. Penelitian dilakukan di Kecamatan Getasan menggunakan metode survei dengan jumlah sampel 32 petani sayur organik pada kelompok tani Tranggulasi. Uji yang dilakukan yaitu Korelasi Rank Spearman. Persepsi petani terhadap penggunaan pupuk organik termasuk dalam kategori tinggi. Umur mempunyai hubungan yang signifikan dengan persepsi petani terhadap tingkat kesesuaian, tingkat kerumitan dan tingkat kemudahan dilihat hasilnya. Tingkat pendidikan tidak mempunyai hubungan yang signifikan dengan persepsi petani terhadap penggunaan pupuk organik. Jumlah anggota keluarga mempunyai hubungan yang signifikan dengan persepsi petani terhadap tingkat kemudahan untuk dicoba dan tingkat kemudahan dilihat hasilnya. Luas lahan mempunyai hubungan yang signifikan dengan persepsi petani terhadap tingkat kerumitan. Pengalaman usahatani mempunyai hubungan yang signifikan dengan persepsi petani terhadap tingkat kesesuaian, kerumitan, kemudahan untuk dicoba.
\end{abstract}

Kata kunci: Persepsi, Pertanian Organik, Petani Sayur

\section{The Perception of Farmers to The Use of Organic Fertilizer in Tranggulasi Group, Getasan Districs, Semarang Regency}

\begin{abstract}
The research aims were to describe the internal and external characteristics of organic vegetable farmers, to describe the perception of farmers on the use of organic fertilizer and to analyze the relationship between internal and external characteristics of farmers with farmers perceptions to use organic fertilizer on Tranggulasi groups. The research was conducted in Getasan Districts using survey method with 32 respondents. Spearman rank correlation was used to analyze the data. The perception of farmers on the use of organic fertilizer on Tranggulasi group was in high category. Age had a significant relationship with the perception of farmers on the level of compatibility, the level of complexity and the level of observability. The level of education had no a significant relationship with the perception of farmers on the use of organic fertilizers. The number of family members had a significant relationship with the perception of farmers to the level of trialability and the level of observability. Land size had a significant relationship with the perception of farmers to the level of complexity. Farming experience had a significant relationship with the perception of farmers on the level of compatibility, complexity and trialability.
\end{abstract}

Keywords: Perception, Organic farming, Vegetable farmer

\section{PENDAHULUAN}

Indonesia sebagai negara agraris, sebagian besar masyarakatnya bekerja pada sektor pertanian. Sektor pertanian sangat penting dalam perekonomian negara Indonesia. Untuk dapat mencapai kesejahteraan, pembangunan ekonomi juga harus bertumpu pada pertanian. Pembangunan pertanian masa depan merupakan proses berkelanjutan, dimana peningkatan, pendalaman, perluasan dan pembaharuan pembangunan pertanian yang telah dilaksanakan sebelumnya. 
Kecamatan Getasan adalah salah satu kecamatan yang berada di Kabupaten Semarang dan merupakan daerah agraris serta mempunyai potensi pengembangan usahatani sayuran. Masyarakat di Kecamatan Getasanrata-rata melakukan usahatani sayuran. Desa Batur merupakan salah satu desa yang terdapat di Kecamatan Getasan, dimana produksi utamanya adalah sayur yang sudah bersertifikat organik. Namun, belum sepenuhnya petani di Desa ini menerapkan pola pertanian secara organik. Pemahaman petani akan inovasi teknologi pertanian organik memerlukan kesiapan dalam mengambil keputusan untuk menerapkan inovasi melalui proses persepsi.

Tingkat adopsi dari suatu inovasi tergantung pada persepsi adopter. Terdapat beberapa atribut yang dapat mendukung persepsi petani terhadap suatu inovasi yaitu keunggulan relatif, tingkat kesesuaian, tingkat kerumitan, tingkat kemudahan untuk dicoba dan dapat dilihat hasil (A. W van den Ban dan H.S. Hawkins, 2003). Penelitian persepsi petani terhadap penggunaan pupuk organik diperlukan guna memberikan gambaran dan saran dalam upaya peningkatan adopsi penggunaan pupuk organik pada usahatani sayuran.

\section{METODE PENELITIAN}

Pada penelitian ini metode yang digunakan adalah survei. Metode survei merupakan riset yang diadakan untuk memperoleh fakta-fakta tentang gejala-gejala atas permasalahan yang timbul. Survei dapat dilakukan dengan cara sensus maupun sampling (Umar, 2003). Penelitian dilaksanakan pada bulan FebruariMaret 2018 pada Kelompok Tani Tranggulasi di Desa Batur, Kecamatan Getasan, Kabupaten Semarang. Metode penentuan wilayah penelitian dilakukan secara sengaja dengan beberapa kriteria tertentu, yaitu merupakan salah satu kelompok tani yang sudah bersertifikat organik serta merupakan penghasil sayuran organik di Kecamatan Getasan. Metode yang digunakan dalam pengambilan sampel adalah metode sensus yaitu mengamati seluruh anggota populasi. Sensus merupakan suatu teknik/cara pengumpulan data secara menyeluruh, dimana seluruh elemen populasi diselidiki satu per satu. Populasi pada penelitian ini adalah seluruh anggota kelompok tani Tranggulasi yang berjumlah 32 orang. Pengumpulan data dikumpulkan melalui wawancara, observasi dan studi pustaka. Data primer diperoleh dari hasil wawancara dengan petani. Data sekunder diperoleh dari berbagai literatur, hasil penelitian terlebih dahulu. Metode analisis yang digunakan adalah metode deskriptif kuantatif. Analisis deskriptif digunakan untuk menganalisis data dengan mendeskripsikan atau menggambarkan data yang dikumpulkan dengan apa adanya. Analisis kuantitatif yang digunakan yaitu analisis korelasi rank Spearman dengan menggunakan SPSS. Analisis ini digunakan untuk menganalisis hubungan secara parsial antara variabel independen dengan variabel dependen. Perhitungan pada korelasi rank Spearman bisa digunakan untuk menghitung koefisien korelasi pada data ordinal dan penggunaan asosiasi pada statistik nonparametrik (Nugroho et al., 2008). Persamaan korelasi Rank Spearman yang digunakan yaitu:

$r=1-\frac{6\left(\sum_{i=1}^{n} d_{i}^{2}\right)}{n\left(n^{2}-1\right)}$

Keterangan:

$\mathrm{R}=$ Koefisien korelasi rank Spearman

$\mathrm{n}$ = Banyaknya pasangan data

$X=$ Selisih dari tiap pasangan rangking

$\mathrm{d}_{\mathrm{i}}=$ Selisih rangking antar variabel

Tabel 1. Interval Koefisien Korelasi Rank Spearman

\begin{tabular}{cr}
\hline $\begin{array}{c}\text { Interval Koefisien } \\
\text { Korelasi }\end{array}$ & Interpretasi \\
\hline $0,00-0,19$ & Sangat \\
$0,20-0,39$ & Lemah \\
$0,40-0,59$ & Lemah \\
$0,60-0,79$ & Sedang \\
$0,80-1,00$ & Kuat \\
\hline
\end{tabular}

Penerimaan dan penolakan hipotesis yang digunakan dalam penelitian ini adalah sebagai berikut: 
- Tidak ada hubungan signifikan antara karakteristik internal dan karakteristik eksternal petani dengan persepsi petani terhadap penggunaan pupuk organik pada kelompok tani Tranggulasi $\left(\mathrm{H}_{0}: \rho=0\right)$

- Ada hubungan signifikan antara karakteristik internal dan karakteristik eksternal petani dengan persepsi petani terhadap penggunaan pupuk organik pada kelompok tani Tranggulasi $(\mathrm{H} 1: \rho \neq 0)$.

\section{HASIL DAN PEMBAHASAN}

\subsection{Karakteristik Petani}

\subsubsection{Umur}

Petani pada kelompok tani Tranggulasi memiliki umur antara 40-50 tahun yaitu 9 orang (28\%), antara umur 51-61 tahun yaitu 13 orang $(41 \%)$ dan antara umur $62-$ 83 tahun yaitu 4 orang (12\%). Berdasarkan hasil ini dapat dikatakan bahwa petani pada kelompok tani Tranggulasi termasuk kedalam kategori umur produktif, sehingga dapat dikatakan bahwa petani pada kelompok tani ini sebagian besar masih produktif melakukan usahataninya.Penduduk Indonesia menurut kelompok umur terdiri dari penduduk berusia muda (0-14 tahun), usia produktif (15-64 tahun) dan kelompok usia $\geq 65$ tahun (BPS, 2016).

\subsubsection{Tingkat Pendidikan}

Kriteria tingkat pendidikan adalah merupakan latar belakang pendidikan formal dan informal yang pernah ditempuh. Berdasarkan Tabel 3 diperoleh bahwa mayoritas tingkat pendidikan petani dalam penelitian ini adalah tamatan SD (Sekolah Dasar), yaitu sebanyak 23 orang $(72 \%)$, tingkat pendidikan menengah (SMP) sebanyak 4 orang (13\%). Sehingga dapat disimpulkan bahwa tingkat pendidikan petani pada kelompok tani Tranggulasi tergolong kedalam tingkat rendah, namun masih terdapat beberapa petani yang sudah menempuh pendidikan tingkat tinggi. Petani berpendidikan rendah maupun tinggi sama-sama berpendapat bahwa menggunakan pupuk organik dalam usahataninya dapat memberikan banyak manfaat bagi kehidupan petani seperti kesehatan dan keuntungan dalam berusahatani.

\subsubsection{Jumlah Anggota Keluarga}

Jumlah anggota keluarga merupakan jumlah anggota keluarga dalam rumah tangga responden.

Berdasarkan Tabel 4 dapat diketahui bahwa mayoritas petani memiliki jumlah anggota keluarga antara 5-6, yaitu 17 responden $(53 \%)$ dan jumlah anggota keluarga paling sedikit antara 1-2 orang, yaitu 1 responden (3\%). Hal ini menunjukkan bahwa petani pada penelitian ini termasuk petani yang memiliki jumlah anggota keluarga yang banyak. Menurut pendapat Gaol et al. (2016) mengatakan bahwa jumlah anggota keluarga yang semakin banyak dapat berpengaruh terhadap pengeluaran petani yang lebih besar. Jumlah anggota keluarga yang banyak juga dapat mengurangi jumlah tenaga kerja yang dibutuhkan oleh petani dari luar.

\subsubsection{Luas Lahan}

Luas lahan merupakan hamparan areal tanah yang digarap oleh responden. Luas lahan adalah salah satu faktor produksi yang tidak dapat dipisahkan di dalam berusahatani.

Berdasarkan Tabel 5 dapat diketahui bahwa mayoritas petani memiliki luas adalah antara $0,05-0,25$ ha, yaitu 22 orang $(68 \%)$ dan petani paling sedikit memiliki luas lahan antara $0,68-0,88$ ha, yaitu 1 orang (3\%). Dari hasil ini dapat disimpulkan bahwa petani pada kelompok tani Tranggulasi tergolong memiliki luas lahan yang sempit yaitu kurang dari 1 ha. Petani pada kelompok tani Tranggulasi sebagian besar memiliki tanah dari harta warisan yang turun temurun dari keluarganya, sehingga petani di kelompok tani ini memaksimalkan lahan yang dimiliki untuk melakukan pertanian organik.

\subsubsection{Pengalaman Usahatani}

Pengalaman berusahatani merupakan lamanya responden berusahatani. 
Agrisaintifika

Jurnal Ilmu-Ilmu Pertanian

Vol 3, No. 1, 2019

Simatupang, et al. 2019

Berdasarkan Tabel 6 dapat diketahui bahwa responden pada penelitian ini lebih banyak yang memiliki pengalaman berusahatani antara 16-19 tahun yaitu 19 orang (59\%) dan paling sedikit antara 4-7 tahun, yaitu 1 orang (3\%). Pengalaman berusahatani yang sudah lama dapat mempengaruhi respon petani yang tinggi dalam penerapan inovasi yang baru seperti penerapan pupuk organik dalam pertanian.

\subsection{Persepsi Petani Terhadap Penggunaan Pupuk Organik}

Persepsi petani terhadap penggunaan pupuk organik pada kelompok tani Tranggulasi dalam penelitian ini terdiri dari penilaian dan pernyataan petani tentang pupuk organik dari tingkat keuntungan relatif, kesesuaian, kerumitan, kemudahan untuk dicoba dan tingkat kemudahan dilihat hasilnya.

Berdasarkan Tabel 7 dapat diketahui bahwa persepsi petani terhadap penggunaan pupuk organik pada kelompok tani Tranggulasi tergolong kedalam kriteria tinggi, yaitu sebanyak 31 orang (97\%). Rataan skor persepsi petani yang diperoleh sebesar 109 dari skor minimal 25 dan skor maksimal 125.

Berdasarkan tingkat keuntungan relatif, sebagian besar petani setuju bahwa penggunaan pupuk organik memberikan manfaat bagi usahatani baik secara ekonomis maupun secara teknis. Tenaga kerja yang dibutuhkan oleh petani untuk membudidayakan sayuran dengan pupuk organik lebih sedikit dibandingkandengan budidaya sayuran menggunakan pupuk kimia. Hal ini dikarenakan

pengerjaan budidaya sayur organik dikerjakan dengan menggunakan tenaga kerja keluarga.Budidaya sayur menggunakan pupuk organik secara ekonomis lebih menguntungkan karena biaya yang dikeluarkan lebih sedikit, dimana petani membuat pupuk organik sendiri dengan menggunakan bahanbahan yang dapat diperoleh dari lingkungan sekitar.
Berdasarkan tingkat kesesuaian, sebagian besar petani setuju bahwa penggunaan pupuk organik dapat menjaga kelestarian lingkungan karena pupuk yang digunakan berasal dari alam, mudah diperoleh bahan bakunya dari lingkungan sekitar serta mudah dalam pembuatannya. Penggunaan pupuk organik dapat menjaga kelestarian lingkungan dapat dilihat dari kondisi tanah yang semakin subur dan sehat, kondisi tanaman serta dari kondisi lingkungan hidup petani yang terbebas dari penggunaan pupuk berbahan kimia.Menurut pendapat Tedjaningsih et al. (2017) mengatakan bahwa tingkat kesesuaian dapat dilihat dari adanya kesesuaian antara penggunaan pupuk organik dengan nilai-nilai, kebiasaan masyarakat, kepercayaan yang berlaku disekitar petani dan kebutuhan petani.

Berdasarkan tingkat kerumitan, mayoritas petani setuju bahwa penggunaan pupuk organik mudah untuk diterapkan dalam berusahatani. Pupuk organik yang digunakan oleh petani pada kelompok tani Tranggulasi yaitu pupuk padat dan pupuk cair. Pupuk padat dapat dibuat secara individu dan pupuk cair dapat dibuat secara bersama dengan kelompok tani, karena sebagian besar petani memiliki ternak sendiri, sehingga dapat mengelola pupuk padat dari kotoran ternak yang dimilikinya. Produk pertanian dengan pupuk organik mudah untuk dijual dan dipasarkan karena sudah memiliki pasar tetap, seperti Superindo, Transmart, pasar lokal dan lainlain.

Berdasarkan tingkat kemudahan untuk dicoba, sebagian besar petani setuju bahwa penggunaan pupuk organik mudah untuk diterapkan. Petani memutuskan untuk menggunakan pupuk organik setelah melakukan uji coba terlebih dahulu dan dengan adanya motivasi serta anjuran yang diberikan oleh ketua kelompok tani dan teman/sesama petani untuk melakukan pertanian organik. Kegiatan penyuluhan yang dilakukan oleh penyuluh kepada kelompok tani Tranggulasi juga memberi kemudahan bagi petani dalam aplikasi pupuk organik. Adanya dukungan dari pemerintah atau kelompok tani juga 
Agrisaintifika

Jurnal Ilmu-Ilmu Pertanian

Vol 3, No. 1, 2019

Simatupang, et al. 2019

dapat mempermudah petani untuk menerapkan pertanian organik.

Berdasarkan tingkat kemudahan dilihat hasilnya, sebagian besar petani setuju bahwa penggunaan pupuk organik dapat memberikan kemudahan bagi petani dalam mengamati perbedaan yang dilihat maupun dirasakan oleh petani. Petani mengatakan bahwa mudah membedakan mutu serta kualitas dari hasil produk pertanian dengan menggunakan pupuk organik dengan produk pertanian non-organik, baik dari segi warna, serta ketahanan produk setelah dipanen.

\subsection{Hubungan Antara Karakteristik Internal dan Eksternal Petani dengan Persepsi Petani Untuk Menggunakan Pupuk Organik Pada Kelompok Tani Tranggulasi}

Karakteristik internal petani terdiri dari umur, tingkat pendidikan, jumlah anggota keluarga. Karakteristik eksternal yaitu luas lahan,pengalaman usahatani. Persepsi petani dapatdilihat dari: tingkat keuntungan relatif, tingkat kesesuaian, tingkat kerumitan, tingkat kemudahan untuk dicoba serta tingkat kemudahan dilihat hasilnya.

\subsubsection{Hubungan antara umur (X1) dengan persepsi petani terhadap penggunaan pupuk organik $(\mathrm{Y})$}

Berdasarkan Tabel 8 dapat diketahui bahwa nilai signifikansi yang diperoleh sebesar 0,362 nilai tersebut $\geq 0,05$ maka $\mathrm{H} 0$ diterima dan $\mathrm{H} 1$ ditolak, artinya bahwa tidak ada hubungan secara signifikan antara umur dengan persepsi petani terhadap tingkat keuntungan relatif.Tanda positif pada nilai korelasi menunjukkan bahwa semakin tinggi umur maka semakin tinggi pula persepsi petani terhadap tingkat keuntungan relatif, artinya memiliki hubungan yang searah.

Nilai signifikansi antara variabel umur dengan persepsi petani terhadap tingkat kesesuaian sebesar 0,000 nilai tersebut $\leq$ 0,05 maka $\mathrm{H} 0$ ditolak dan $\mathrm{H} 1$ diterima, artinya terdapat hubungan yang signifikan antara umur dengan persepsi petani terhadap tingkat kesesuaian. Nilai koefisien korelasi sebesar $0,634^{* *}$ artinya umur memiliki korelasi yang kuat dengan persepsi petani terhadap tingkat kesesuaian. Fakta dilapangan diperoleh bahwa petani sudah melakukan pertanian dengan menggunakan pupuk organik selama 18 tahun. Petani mampu membuktikan bahwa penggunaan pupuk organik telah memberikan manfaat bagi petani.

Nilai signifikansi antara variabel umur dengan persepsi petani terhadap tingkat kerumitan sebesar 0,000 nilai tersebut $\leq$ 0,05 maka $\mathrm{H} 0$ ditolak dan $\mathrm{H} 1$ diterima, artinya terdapathubungan yang signifikan antara umur dengan persepsi petani terhadap tingkat kerumitan. Nilai koefisien korelasi sebesar $0,616^{* *}$ memiliki arti bahwa umur memiliki korelasi yang kuat dengan persepsi petani terhadap tingkat kerumitan. Semakin produktif umur petani maka persepsi terhadap tingkat kerumitan untuk menggunakan pupuk organik akan semakin baik. Hal ini dapat dilihat dari kemudahan yang dirasakan oleh petani dalam membuat pupuk organik sendiri, kemudahan dalam memperoleh informasi mengenai pupuk organik.

Nilai signifikansi antara variabel umur dengan persepsi petani terhadap tingkat kemudahan untuk dicoba sebesar 0,220 nilai tersebut $\geq 0,05$ maka $\mathrm{HO}$ diterima dan $\mathrm{H} 1$ ditolak, artinya tidak ada hubungan secara signifikan antara umur dengan persepsi petani terhadap tingkat kemudahan untuk dicoba. Nilai koefisien korelasi yang diperoleh sebesar 0,223 artinya umur memiliki korelasi yang lemah dengan persepsi petani terhadap tingkat kemudahan untuk dicoba.

Nilai signifikansi antara variabel umur dengan persepsi petani terhadap tingkat kemudahan dilihat hasilnya adalah 0,001 nilai tersebut $\leq 0,05$ maka $\mathrm{HO}$ ditolak dan $\mathrm{H} 1$ diterima, artinya terdapat hubungan yang signifikan antara umur dengan persepsi petani terhadap tingkat kemudahan dilihat hasilnya. Nilai koefisien korelasi sebesar $0,538^{* *}$ berarti bahwa umur memiliki korelasi yang sedang dengan persepsi petani terhadap tingkat kemudahan dilihat hasilnya. Semakin produktif umur petani maka persepsi terhadap tingkat kemudahan dilihat 
hasilnya terhadap penggunaan pupuk organik akan semakin baik. Menurut pendapat Wardhani dan Prasetiyo (2016) mengatakan bahwa umur petani dapat mempengaruhi kemampuan fisik dan respon terhadap hal-hal yang baru dalam melakukan usahataninya. Bertambahnya usia dapat berpengaruh terhadap pola pikir cara kerja dan cara hidup.

\subsubsection{Hubungan antara tingkat pendidikan (X2) dengan persepsi petani terhadap penggunaan pupuk organik (Y)}

Nilai koefisien korelasi sebesar 0,088 artinya tingkat pendidikan memiliki korelasi yang sangat lemah dengan persepsi petani terhadap tingkat keuntungan relatif. Hubungan yang tidak signifikan dan korelasi yang sangat lemah menunjukkan bahwa tinggi rendahnya pendidikan formal seseorang tidak mempengaruhi persepsi petani terhadap penggunaan pupuk organik, karena petani sangat mudah memperoleh informasi serta pengetahuan melalui pendidikan non formal seperti adanya kegiatan penyuluhan, seminar yang terkait dengan pertanian organik. Hasil penelitian menunjukkan bahwa jika tingkat pendidikan tidak berhubungan nyata dengan pendidikan non formal, maka meningkatkan pengetahuan dan keterampilan dapat dilakukan melalui kegiatan penyuluhan untuk memberikan beragam informasi kepada petani, sehingga mempengaruhi keputusan petani dalam menjalankan usahatani (Widiyastuti et al., 2016).

Nilai signifikansi antara variabel tingkat pendidikan dengan persepsi petani terhadap tingkat kesesuaian adalah 0,765 nilai tersebut $\geq 0,05$ maka $\mathrm{H} 0$ diterima dan $\mathrm{H} 1$ ditolak, artinya tidak ada hubungan secara signifikan antara tingkat pendidikan dengan persepsi petani terhadap tingkat kesesuaian.Tingkat pendidikan petani tidak mempengaruhi persepsinya terhadap tingkat kesesuaian. Petani menerapkan pertanian organik karena memiliki kesadaran dan dengan adanya motivasi dari penyuluh serta ketua kelompok tani bahwa penggunaan pupuk organik dapat memberikan manfaat kepada petani untuk memenuhi hidup yang lebih sehat.
Nilai signifikansi antara variabel tingkat pendidikandenganpersepsipetaniterhadapti ngkatkerumitanadalah0,624

nilaitersebut $\geq 0,05$ makaH0diterimadanH1 dit olak,artinya tidak ada hubungan secara signifikan antara tingkat pendidikan dengan persepsi petani terhadap tingkat kerumitan. Petani berpendidikan rendah maupun tinggi sama-sama berpendapat bahwa tingkat kerumitan dalam pertanian dengan menggunakan pupuk organik tidak serumit dengan pertanian konvensional.Petani mudah membuat pupuk organik sendiri dengan menggunakan bahan-bahan yang mudah diperoleh dari lingkungan sekitar.

Nilai signifikansi antara variabel tingkat pendidikan dengan persepsi petani terhadap tingkat kemudahan untuk dicoba adalah 0,663 nilai tersebut $\geq 0,05$ maka $\mathrm{HO}$ diterima dan $\mathrm{H} 1$ ditolak, artinya tidak ada hubungan secara signifikan antara tingkat pendidikan dengan persepsi petani terhadap tingkat kemudahan untuk dicoba. Tanda positif pada nilai korelasi menunjukkan bahwa semakin tinggi pendidikan maka semakin tinggi pula persepsi petani terhadap tingkat kemudahan untuk dicoba, artinya memiliki hubungan yang searah. Petani memutuskan untuk menerapkan pertanian dengan menggunakan pupuk organik setelah melakukan ujicoba terlebih dahulu pada lahan sempit dan dengan dosis pupuk organik yang sedikit. Adanya dukungan yang diberikan oleh pemerintah dan ketua kelompok tani juga mempengaruhi petani untuk menerima inovasi pertanian dengan menggunakan pupuk organik.

Nilai signifikansi antara variabel tingkat pendidikan dengan persepsi petani terhadap tingkat kemudahan dilihat hasilnya adalah 0,740 nilai tersebut $\geq 0,05$ maka $\mathrm{H} 0$ diterimadan $\mathrm{H} 1$ ditolak, artinya tidak ada hubungan secara signifikan antara tingkat pendidikan dengan persepsi petani terhadap tingkat kemudahan dilihat hasilnya. Nilai koefisien korelasi sebesar 0,061 artinya tingkat pendidikan memiliki korelasi yang sangat lemah dengan persepsi petani terhadap tingkat kemudahan dilihat hasilnya. Keeratan hubungannya termasuk lemah karena nilai 
Agrisaintifika

Jurnal Ilmu-Ilmu Pertanian

Vol 3, No. 1, 2019

koefisien korelasi kurang dari 0,5. Tanda negatif pada nilai korelasi menunjukkan bahwa semakin rendah pendidikan maka semakin tinggi persepsi petani terhadap tingkat kemudahan dilihat hasilnya, artinya memiliki hubungan yang berlawanan arah.

Variabel tingkat pendidikan memiliki hubungan yang tidak signifikan menunjukkan tidak adanya pengaruh tingkat pendidikan petani terhadap persepsinya dalam menggunakan pupuk organik.

\subsubsection{Hubungan antara jumlah anggota keluarga (X3) dengan persepsi petani terhadap penggunaan pupuk organik (Y)}

Berdasarkan Tabel 8 dapat diketahui bahwa nilai signifikansi antara variabel jumlah anggota keluarga dengan persepsi petani terhadap tingkat keuntungan relatif adalah 0,440 nilai ini $\geq 0,05$ maka $\mathrm{HO}$ diterima dan $\mathrm{H} 1$ ditolak, artinya tidak ada hubungan secara signifikan antara jumlah anggota keluarga dengan persepsi petani terhadap tingkat keuntungan relatif. Nilai koefisien korelasi sebesar 0,142 artinya jumlah anggota keluarga memiliki korelasi yang sangat lemah dengan persepsi petani terhadap tingkat keuntungan relatif. Hubungan yang tidak signifikan menunjukkan semakin banyak jumlah anggota keluarga menyebabkan persepsi petani terhadap tingkat keuntungan relatif semakin menurun. Jumlah anggota keluarga yang semakin banyak dapat menambah kebutuhan biaya keluarga petani. Hal ini sejalan dengan penelitian Azwar et al. (2016) yang mengatakan bahwa jumlah tanggungan keluarga berhubungan tidak signifikan dengan partisipasi petani dalam pelaksanaan rehabilitasi tanaman kakao. Semakin banyak jumlah anggota keluarga maka semakin menurun partisipasi petani. Penambahan jumlah anggota keluarga belum berfungsi sebagai tenaga kerja yang produktif sehingga dapat mengakibatkan penambahan kebutuhan biaya hidup.

Nilai signifikansi antara variabel jumlah anggota keluarga dengan persepsi petani terhadap tingkat kesesuaian adalah 0,360 nilai tersebut $\geq 0,05$ maka $\mathrm{HO}$ diterima dan $\mathrm{H} 1$ ditolak, artinya tidak ada hubungan secara signifikan antara jumlah anggota keluarga dengan persepsi petani terhadap tingkat kesesuaian. Hubungan yang tidak signifikan dan korelasi yang sangat lemah menunjukkan bahwa sedikit banyaknya jumlah anggota keluarga tidak mempengaruhi persepsi petani terhadap penggunaan pupuk organik.

Nilai signifikansi antara variabel jumlah anggota keluarga dengan persepsi petani terhadap tingkat kerumitan adalah 0,063 nilai tersebut $\geq 0,05$ maka $\mathrm{H} 0$ diterima dan $\mathrm{H} 1$ ditolak, artinya tidak terdapat hubungan yang signifikan antara jumlah anggota keluarga dengan persepsi petani terhadap tingkat kerumitan.Hubungan yang tidak signifikan menunjukkan bahwa jumlah anggota keluarga tidak berpengaruh dengan persepsi petani terhadap tingkatkerumitan. Sedikit banyaknya jumlah anggota keluarga tidak memberikan pengaruh kepada petani untuk mengambil inovasi pertanian dengan menggunakan pupuk organik. Petani yang memiliki jumlah anggota keluarga yang banyak maupun sedikit sama-sama mudah untuk melakukan pertanian dengan menggunakan pupuk organik.

Nilai signifikansi antara variabel jumlah anggota keluarga dengan persepsi petani terhadap tingkat kemudahan untuk dicoba adalah 0,028 nilai tersebut $\leq 0,05$ maka $\mathrm{HO}$ ditolak dan $\mathrm{H} 1$ diterima, artinya bahwa terdapat hubungan yang signifikan antara jumlah anggota keluarga dengan persepsi petani terhadap tingkat kemudahan untuk dicoba. Nilai koefisien korelasi yang diperoleh sebesar $0,388^{*}$.Tanda positif pada nilai korelasi menunjukkan bahwa semakin banyak jumlah anggota keluarga maka semakin tinggi pula persepsi petani terhadap tingkat kemudahan untuk dicoba, artinya memiliki hubungan yang searah. Semakin banyak jumlah anggota keluarga dapat memberikan kemudahan kepada petani untuk menerapkan pertanian dengan menggunakan pupuk organik. Dapat dilihat dari pengaruh jumlah anggota keluarga yang dapat membantu petani dalam menyediakan bahan-bahan dan membuat pupuk organik sendiri.

Nilai signifikansi antara variabel jumlah anggota keluarga dengan persepsi petani 
Agrisaintifika

Jurnal Ilmu-Ilmu Pertanian

Vol 3, No. 1, 2019

Simatupang, et al. 2019

terhadap tingkat kemudahan dilihat hasilnya adalah 0,028 nilai tersebut $\leq 0,05$ maka $\mathrm{H} 0$ ditolak dan $\mathrm{H} 1$ diterima, artinya terdapat hubungan yang signifikan antara jumlah anggota keluarga dengan persepsi petani terhadap tingkat kemudahan dilihat hasilnya. Nilai koefisien korelasi sebesar $0,393^{*}$ artinya jumlah anggota keluarga memiliki korelasi yang lemah dengan persepsi petani terhadap tingkat kemudahan dilihat hasilnya. Tanda positif pada nilai korelasi menunjukkan bahwa semakin banyak jumlah anggota keluarga maka semakin tinggi pula persepsi petani terhadap tingkat kemudahan dilihat hasilnya, artinya memiliki hubungan yang searah.

\subsubsection{Hubungan antara luas lahan (X4) dengan persepsi petani terhadap penggunaan pupuk organik ( $\mathrm{Y}$ )}

Nilai signifikansi antara variabel luas lahan dengan persepsi petani terhadap tingkat keuntungan relatif adalah 0,715 nilai tersebut $\geq 0,05$ maka $\mathrm{H} 0$ diterima dan $\mathrm{H} 1$ ditolak, artinya tidak ada hubungan secara signifikan antara luas lahan dengan persepsi petani terhadap tingkat keuntungan relatif. Hubungan yang tidak signifikan menunjukkan bahwa ada hubungan yang tidak nyata diantara petani yang memiliki luas lahan sempit maupun sebaliknya dengan persepsi petani terhadap penggunaan pupuk organik. Petani mengelola lahan yang dimiliki untuk menghasilkan produk pertanian seoptimal mungkin untuk memenuhi kebutuhan serta kesejahteraan keluarganya. Hal ini sesuai dengan pendapat Widiyastuti et al. (2016) yang mengatakan bahwa luas sempitnya suatu lahan tidak berhubungan nyata dengan persepsi seorang petani. Petani dalam menjalankan usahatani tidak melihat seberapa luas lahan yang dimiliki namun melihat resiko apa yang akan terjadi apabila petani tersebut mengadopsi sebuah teknologi pertanian yang baru maupun yang sudah dilakukan sebelumnya tetapi masih mengalami kegagalan dalam berusahatani.

Nilai signifikansi antara variabel luas lahan dengan persepsi petani terhadap tingkat kesesuaian adalah 0,315 nilai tersebut $\geq$ 0,05 maka $\mathrm{H} 0$ diterima dan $\mathrm{H} 1$ ditolak, artinya tidak ada hubungan secara signifikan antara luas lahan dengan persepsi petani terhadap tingkat kesesuaian. Hubungan yang tidak signifikan menunjukkan bahwa luas sempitnya lahan yang dimiliki oleh petani tidak memberikan pengaruh terhadap persepsi petani untuk melakukan inovasi baru dalam pertaniannya. Petani menggunakan pupuk organik lebih melihat dampak yang diberikan oleh inovasi yang akan diadopsi.

Nilai signifikansi antara variabel luas lahan dengan persepsi petani terhadap tingkat kerumitan adalah 0,042nilai tersebut $\leq 0,05$ maka $\mathrm{H} 0$ ditolak dan $\mathrm{H} 1$ diterima. Nilai koefisien korelasi sebesar $0,361^{*}$ artinya luas lahan memiliki korelasi yang lemah dengan persepsi petani terhadap tingkat kerumitan. Tanda positif pada nilai korelasi menunjukkan bahwa semakin tinggi luas lahan maka semakin tinggi pula persepsi petani terhadap tingkat kerumitan, artinya memiliki hubungan yang searah. Petani memiliki luas lahan yang sempit, sehingga petani lebih mudah menerapkan pola pertanian dengan menggunakan pupuk organik, karena diperlukan pengamatan yang rutin dari petani terhadap usahataninya.

Nilai signifikansi antara variabel luas lahan dengan persepsi petani terhadap tingkat kemudahan untuk dicoba adalah 0,243 nilai tersebut $\geq 0,05$ maka $\mathrm{H} 0$ diterima dan $\mathrm{H} 1$ ditolak, artinya tidak ada hubungan secara signifikan antara luas lahan dengan persepsi petani terhadap tingkat kemudahan untuk dicoba. Nilai koefisien korelasi sebesar 0,213 artinya luas lahan memiliki korelasi yang lemah dengan persepsi petani terhadap tingkat kemudahan untuk dicoba. Hubungan luas lahan dengan persepsi petani terhadap tingkat kemudahan untuk dicoba tidak memberikan pengaruh kepada petani, karena semua petani memiliki luas lahan yang sempit sehingga sangat mudah untuk melakukan ujicoba terlebih dahulu terhadap pupuk organik, sebelum mengambil keputusan untuk bertani organik.

Nilai signifikansi antara variabel luas lahan dengan persepsi petani terhadap tingkat 
kemudahan dilihat hasilnya adalah 0,182 nilai tersebut $\geq 0,05$ maka $\mathrm{HO}$ diterima dan $\mathrm{H} 1$ ditolak, artinya tidak ada hubungan secara signifikan antara luas lahan dengan persepsi petani terhadap tingkat kemudahan dilihat hasilnya.

\subsubsection{Hubungan antara pengalaman usahatani (X5) dengan persepsi petani terhadap penggunaan pupuk organik (Y)}

Nilai signifikansi antara variabel pengalaman usahatani dengan persepsi petani terhadap tingkat keuntungan relatif adalah 0,082 nilai tersebut $\geq 0,05$ maka $\mathrm{HO}$ diterima dan $\mathrm{H} 1$ ditolak, artinya tidak terdapat hubungan yang signifikan antara pengalaman usahatani dengan persepsi petani terhadap tingkat keuntungan relatif. Nilai koefisien korelasi sebesar 0,312 artinya pengalaman usahatani memiliki korelasi yang lemah dengan persepsi petani terhadap tingkat keuntungan relatif. Pengalaman usahatani petani tidak memberikan pengaruh kepada persepsi petani terhadap tingkat keuntungan relatif. Sedikit banyaknya pengalaman yang dimiliki oleh petani tidak mempengaruhi petani untuk menerima inovasi pertanian organik. Baik petani yang memiliki pengalaman usahatani yang banyak maupun sedikit sama-sama berpendapat bahwa penggunaan pupuk organik dapat memberikan keuntungan bagi petani.

Nilai signifikansi antara variabel pengalaman usahatani dengan persepsi petani terhadap tingkat kesesuaian adalah 0,018 nilai tersebut $\leq 0,05$ maka $\mathrm{H} 0$ ditolak dan $\mathrm{H} 1$ diterima artinya terdapat hubungan yang signifikan antara pengalaman usahatani dengan persepsi petani terhadap tingkat kesesuaian. Nilai koefisien korelasi sebesar $0,416^{*}$ artinya pengalaman usahatani memiliki korelasi sedang dengan persepsi petani terhadap tingkat kesesuaian. Petani berpendapat bahwa penggunaan pupuk organik dalam pertanian telah sesuai dengan kebiasaan petani yang lebih cenderung mengkonsumsi pangan organik, penggunaan pupuk organik sesuai dengan kebutuhan petani serta sesuai terhadap permintaan pasar yang ada. Hasil penelitian Hermawati et al. (2016) menunjukkan pengalaman menggunakan pupuk pupuk organik memiliki hubungan yang signifikan dengan persepsi petani terhadap kesesuaian dan manfaat hasil diamati. Petani yang memiliki pengalaman tinggi akan lebih mengenal baik terhadap pupuk organik, petani percaya dan meyakini bahwa penggunaan pupuk organik ramah lingkungan serta petani lebih paham tehadap perubahan yang terjadi ketika menggunakan pupuk organik.

Nilai signifikansi antara variabel pengalaman usahatani dengan persepsi petani terhadap tingkat kerumitan adalah 0,003 nilai ini $\leq 0,05$ maka $\mathrm{HO}$ ditolak dan $\mathrm{H} 1$ diterima, artinya terdapat hubungan yang signifikan antara pengalaman usahatani dengan persepsi petani terhadap tingkat kerumitan. Nilai koefisien korelasi sebesar $0,509^{*}$ artinya pengalaman usahatani memiliki korelasi yang sedang dengan persepsi petani terhadap tingkat kerumitan. Pengalaman usahatani organik yang semakin tinggi dapat mempengaruhi persepsi petani untuk menggunakan pupuk organik dalam usahataninya. Hal ini sesuai dengan hasil penelitian Kusumo et al. (2017) yang mendapatkan hasil bahwa persepsi petani dipengaruhi secara nyata oleh pengalaman berusahatani. Semakin lama pengalaman petani dalam melakukan usahatani dengan menggunakan pupuk organik maka petani akan semakin terampil dalam menerapkan teknologi pertanian dengan pupuk organik dan semakin tanggap dalam membaca peluang pasar sehingga petani merasakan keuntungan dari hasil pertanian organik baik secara materi maupun dalam menjaga kelestarian lingkungan karena menggunakan teknologi yang ramah lingkungan.

Nilai signifikansi antara variabel pengalaman usahatani dengan persepsi petani terhadap tingkat kemudahan untuk dicoba adalah 0,050 nilai tersebut sama dengan taraf pengujian signifikan sebesar 0,05 maka $\mathrm{H} 0$ ditolak dan $\mathrm{H} 1$ diterima, artinya terdapat hubungan yang signifikan antara pengalaman usahatani dengan persepsi petani terhadap tingkat kemudahan untukdicoba. Nilai koefisien 
Agrisaintifika

Jurnal Ilmu-Ilmu Pertanian

Vol 3, No. 1, 2019

korelasi yang diperoleh sebesar 0,349* artinya pengalaman usahatani memiliki korelasi yang lemah dengan persepsi petani terhadap tingkat kemudahan untuk dicoba. Tanda positif pada nilai korelasi menunjukkan bahwa semakin banyak pengalaman usahatani seseorang maka semakin tinggi pula persepsi petani terhadap tingkat kemudahan untuk dicoba, artinya memiliki hubungan yang searah yaitu semakin tinggi persepsi petani tentang tingkat kemudahan penggunaan pupuk organik seiring dengan bertambahnya pengalaman petani.

Nilai signifikansi antara variabel pengalaman usahatani dengan persepsi petani terhadap tingkat kemudahan dilihat hasilnya adalah 0,077 nilai tersebut $\geq 0,05$ maka $\mathrm{H} 0$ diterima dan $\mathrm{H} 1$ ditolak, artinya tidak terdapat hubungan yang signifikan antara pengalaman usahatani dengan persepsi petani terhadap tingkat kemudahan dilihat hasilnya. Nilai koefisien korelasi yang diperoleh adalah sebesar 0,317 artinya pengalaman usahatani memiliki korelasi yang lemah dengan persepsi petani terhadap tingkat kemudahan dilihat hasilnya. Keeratan hubungannya termasuk lemah karena nilai koefisien korelasi kurang dari 0,5. Tanda positif pada nilai korelasi menunjukkan bahwa semakin banyak pengalaman usahatani seseorang maka semakin tinggi pula persepsi petani terhadap tingkat kemudahan dilihat hasilnya, artinya memiliki hubungan yang searah. Petani yang memiliki pengalaman usahatani organik yang tinggi akan lebih mengerti terhadap penggunaan pupuk organik. Petani lebih percaya bahwa hasil panen dengan menggunakan pupuk organik lebih sehat. Petani lebih mudah membedakan mutu dan keadaan fisik tanaman dengan menggunakan pupuk organik. Hal ini sesuai dengan pendapat Hermawati et al. (2016) yang mengatakan bahwa petani dengan pengalaman yang tinggi akan lebih peka terhadap indikator perubahan yang terjadi ketika menggunakan pupuk organik. Petani dapat menganalisis nyata tidaknya manfaat yang diberikan dari penggunaaan pupuk organik.

\section{KESIMPULAN}

Berdasarkan hasil penelitian dan pembahasan yang mengkaji persepsi petani tentang penggunaan pupuk organik pada kelompok tani Tranggulasi Kecamatan Getasan, Kabupaten Semarang, maka dapat disimpulkan bahwa petani yang menggunakan pupuk organik pada kelompok tani Tranggulasi sebagian besar termasuk dalam kelompok usia produktif, dengan tingkat pendidikan formal sebagian besar lulus SD yaitu $72 \%$. Jumlah anggota keluarga petani rata-rata sebanyak 5-6 orang. Petani mempunyai pengalaman bertani yang termasuk lama yaitu antara 16-19 tahun (59\%). Luas lahan yang digarap oleh petani paling sempit 0,07 ha dan terluas 0,77 ha. Persepsi petani terhadap penggunaan pupuk organik pada kelompok tani Tranggulasi termasuk dalam kategori tinggi. Karakteristik Umur mempunyai hubungan yang signifikan dengan persepsi petani terhadap tingkat kesesuaian, tingkat kerumitan dan tingkat kemudahan dilihat hasilnya. Jumlah anggota keluarga mempunyai hubungan yang signifikan dengan persepsi petani terhadap tingkat kemudahan untuk dicoba dan tingkat kemudahan dilihat hasilnya. Luas lahan mempunyai hubungan yang signifikan dengan persepsi petani terhadap tingkat kerumitan. Pengalaman usahatani mempunyai hubungan yang signifikan dengan persepsi petani terhadap tingkat kesesuaian, tingkat kerumitan dan tingkat kemudahan untuk dicoba. Tingkatpendidikan tidak mempunyai hubungan dengan persepsi petani terhadap penggunaan pupuk organik.

\section{DAFTAR PUSTAKA}

A.W. Van den Ban dan Hawkins. 2003. Penyuluhan Pertanian. Kanisius, Yogyakarta. 
Agrisaintifika

Jurnal Ilmu-Ilmu Pertanian

Vol 3, No. 1, 2019

Simatupang, et al. 2019

Azwar,P. Muljono dan T. Herawati. 2016. Persepsi dan partisipasi petani dalam pelaksanaan rehabilitasi di Kabupaten Sigi Provinsi Sulawesi Tengah. J. Penyuluhan. 12(2): 157-167.

Badan Pusat Statistik. 2016. Statistik Indonesia Tahun 2016. Badan Pusat Statistik, Jakarta Pusat.

Gaol. J. L., V. V. Rantung dan B. Olfie. 2016. Perilaku petani sayur dalam pemanfaatan pupuk organik di Kakaskasen Kota Tomohon. J. Agro-Sosio Ekonomi. 12(3): 117-126.

Hermawati, U., H. Ihsaniyati dan B. W. Utami. 2016. Persepsi petani terhadap karakteristik pupuk organik cair limbah Etanol di Kecamatan Mojolaban. J. Agrista. 4(3): 1-12.

Kusumo. R. A. B., K., A. Charina, A. H. Sadeli dan G. W. Mukti. 2017. Persepsi petani terhadap teknologi budidaya sayuran organik di Kabupaten Bandung Barat. J. Paspalum. 5(2): 19-28.

Nugroho, S., S. Akbar dan R. Vusvitasari. 2008. Kajian hubungan koefisien korelasi Pearson $(r)$, Spearman$r H O(\rho)$, Kendall-Tau ( $\mathrm{T})$, Gamma (G) dan Somers (d $\left.\mathrm{yx}_{\mathrm{x}}\right)$. J. Gradien. 4(2): 372-381.

Tedjaningsih, T., Suyudi dan $H$. Nuryaman. 2017. Persepsi petani terhadap

penggunaanpupukorganikpadaus ahataniMendong.J.Agribisnis.

3(1):64- 72.

Umar, H. 2003. Metode Riset Bisnis. PT Gramedia Pustaka Utama, Jakarta.

Wardhani. R. M. dan E. Prasetiyo. 2016. Faktor-faktor mempengaruhi persepsimasyarakatterhadapbudi dayatanamankakao(Theobromac acaoL.)

(StudikasusdiKecamatanDagang anKabupaten

Madiun).J.IImuPertanian, Kehutanan dan Agroteknologi. 17(1):8-18.

Widiyastuti, E. Widiyanti dan Sutarto, 2016. Persepsi petani terhadap pengembangan System Of Rice Intensification (SRI) di Kecamatan Moga Kabupaten Pemalang. J. Agrista. 4(3): 476485. 
Agrisaintifika

Jurnal Ilmu-Ilmu Pertanian

Vol 3, No. 1, 2019

Simatupang, et al. 2019

\section{LAMPIRAN}

Tabel 2. Jumlah dan Persentase Responden Berdasarkan Kategori Umur

\begin{tabular}{ccc}
\hline Kategori Umur & Jumlah & Persentase \\
\hline--- tahun--- & -- org--- & $---\%-^{---}$ \\
$29-39$ & 6 & 19 \\
$40-50$ & 9 & 28 \\
$51-61$ & 13 & 41 \\
$62-72$ & 2 & 6 \\
$73-83$ & 2 & 6 \\
\hline Jumlah & 32 & 100 \\
\hline
\end{tabular}

Tabel 3. Jumlah dan Persentase Responden Berdasarkan Tingkat Pendidikan

\begin{tabular}{lrc}
\hline \multicolumn{1}{c}{ Pendidikan } & Jumlah & Persentase \\
\hline SD & --- org--- & $---\%---$ \\
SMP atau sederajat & 23 & 72 \\
SMA atau sederajat & 4 & 13 \\
Perguruan Tinggi & 2 & 6 \\
\hline Jumlah & 3 & 9 \\
\hline
\end{tabular}

Tabel4.JumlahdanPersentaseRespondenBerdasarkanJumlahAnggotaKeluarga

\begin{tabular}{ccc}
\hline Kategori Jumlah Anggota Keluarga & Jumlah & Persentase \\
\hline--- orang--- & --- org--- & $---\%---$ \\
$1-2$ & 1 & 3 \\
$3-4$ & 10 & 31 \\
$5-6$ & 17 & 53 \\
$7-8$ & 4 & 13 \\
\hline Jumlah & 32 & 100 \\
\hline
\end{tabular}

Tabel 5. Jumlah dan Persentase Responden Berdasarkan Luas Lahan

\begin{tabular}{ccc}
\hline Kategori Luas Lahan & Jumlah & Persentase \\
\hline--- ha--- & -- org--- & $---\%---$ \\
$0,05-0,25$ & 22 & 68 \\
$0,26-0,46$ & 5 & 16 \\
$0,47-0,67$ & 4 & 13 \\
$0,68-0,88$ & 1 & 3 \\
\hline Jumlah & 32 & 100 \\
\hline
\end{tabular}


Agrisaintifika

Jurnal Ilmu-Ilmu Pertanian

Vol 3, No. 1, 2019

Simatupang, et al. 2019

Tabel 6. Jumlah dan Persentase Responden Berdasarkan Pengalaman Usahatani

\begin{tabular}{ccc}
\hline Pengalaman usahatani & Jumlah & Persentase \\
\hline--- tahun--- & --- org--- & $---\%---$ \\
$4-7$ & 1 & 3 \\
$8-11$ & 4 & 13 \\
$12-15$ & 8 & 25 \\
$16-19$ & 19 & 59 \\
\hline Jumlah & 32 & 100 \\
\hline
\end{tabular}

Tabel 7. Jumlah dan Persentase Responden Berdasarkan Kategori Persepsi Petani Terhadap Penggunaan Pupuk Organik

\begin{tabular}{|c|c|c|}
\hline $\begin{array}{l}\text { Kategori persepsi petani terhadap } \\
\text { penggunaan pupuk organik }\end{array}$ & Jumlah & Persentase \\
\hline ---skor--- & ---org--- & ---\%"--- \\
\hline Rendah $\quad(25-57)$ & 0 & 0 \\
\hline Sedang $\quad(58-90)$ & 1 & 3 \\
\hline Tinggi $\quad(91-125)$ & 31 & 97 \\
\hline Total & 32 & 100 \\
\hline Min $-\max$ & & $25-125$ \\
\hline Skor rata-rata & & 109 \\
\hline
\end{tabular}


Agrisaintifika

Jurnal Ilmu-Ilmu Pertanian

Vol 3, No. 1, 2019

Simatupang, et al. 2019

Tabel 8. Hubungan Antara Karakteristik Internal dan Eksternal Petani dengan Persepsi Petani Untuk Menggunakan Pupuk Organik Pada Kelompok Tani Tranggulasi

\begin{tabular}{|c|c|c|c|c|c|}
\hline \multirow[b]{2}{*}{$\begin{array}{c}\text { Karakteristik } \\
\text { internal dan } \\
\text { eksternal }\end{array}$} & \multicolumn{5}{|c|}{$\begin{array}{l}\text { Koefisien korelasi rank Spearman (rs), Sig. (2-tailed) } \\
\text { Persepsi petani terhadap penggunaan pupukorganik }\end{array}$} \\
\hline & $\begin{array}{c}\text { Tingkat } \\
\text { Keuntungan } \\
\text { Relatif }\end{array}$ & $\begin{array}{l}\text { Tingkat } \\
\text { Kesesuaian }\end{array}$ & $\begin{array}{l}\text { Tingkat } \\
\text { Kerumitan }\end{array}$ & $\begin{array}{c}\text { Tingkat } \\
\text { Kemudahan } \\
\text { Untuk } \\
\text { Dicoba }\end{array}$ & $\begin{array}{c}\text { Tingkat } \\
\text { Kemudahan } \\
\text { Dilihat } \\
\text { Hasilnya }\end{array}$ \\
\hline \multirow[t]{2}{*}{ Umur } & 0,167 & $0,634^{* *}$ & $0,616^{* *}$ & 0,223 & $0,538^{* *}$ \\
\hline & 0,362 & 0,000 & 0,000 & 0,220 & 0,001 \\
\hline \multirow[t]{2}{*}{$\begin{array}{c}\text { Tingkat } \\
\text { Pendidikan }\end{array}$} & 0,088 & $-0,055$ & 0,090 & 0,080 & $-0,061$ \\
\hline & 0,633 & 0,765 & 0,624 & 0,663 & 0,740 \\
\hline \multirow{2}{*}{$\begin{array}{c}\text { Jumlah } \\
\text { Anggota } \\
\text { Keluarga }\end{array}$} & 0,142 & 0,167 & 0,332 & $0,388^{*}$ & $0,393^{*}$ \\
\hline & 0,440 & $\underline{0,360}$ & $\underline{0,063}$ & 0,028 & 0,026 \\
\hline \multirow[t]{2}{*}{ Luas Lahan } & 0,067 & 0,183 & $0,361^{*}$ & 0,213 & 0,242 \\
\hline & 0,715 & 0,315 & 0,042 & 0,243 & 0,182 \\
\hline \multirow[t]{2}{*}{$\begin{array}{l}\text { Pengalaman } \\
\text { Usahatani }\end{array}$} & 0,312 & $0,416^{*}$ & $0,509^{* *}$ & $0,349^{*}$ & 0,317 \\
\hline & 0,082 & 0,018 & 0,003 & 0,050 & 0,077 \\
\hline
\end{tabular}

Keterangan: * signifikan pada $\alpha=0,05$

$$
\text { ** signifikan pada } \alpha=0,01
$$

